\title{
An integrated ethical approach to bioethical decision- making: A proposed model for ministers
}

\author{
Author: \\ Magdalena C. de Lange ${ }^{1}$ \\ Affiliation: \\ ${ }^{1}$ School of Ecclesiastical \\ Sciences, Faculty of Theology, \\ Potchefstroom Campus, \\ North-West University, \\ South Africa \\ Correspondence to: \\ Hans van Deventer \\ Email: \\ hans.vandeventer@nwu.ac.za \\ Postal address: \\ PO Box 1174, Vanderbijlpark \\ 1900, South Africa \\ Dates: \\ Received: 14 Mar. 2011 \\ Accepted: 02 Sept 2011 \\ Published: 19 Oct. 2012 \\ How to cite this article: \\ De Lange, M.C., 2012, 'An \\ integrated ethical approach \\ to bioethical decision- \\ making: A proposed model \\ for ministers', In die Skriflig/ \\ In Luce Verbi 46(1), Art. \\ \#55, 7 pages. http://dx.doi. \\ org/10.4102/ids.v46i1.55

\section{Note:} \\ Shortly after this article \\ was completed, Dr. Leentie \\ de Lange passed away on \\ 05 July 2011 after a long \\ and courageous battle of \\ fourteen and a half years \\ against cancer. Prof. Hans \\ van Deventer was one of the \\ promoters who supervised \\ the thesis from which this \\ article emanated, and agreed \\ to act as correspondent.
}

(C) 2012. The Authors. Licensee: AOSIS OpenJournals. This work is licensed under the Creative Commons Attribution License.
This article outlined a model for guidance in 'doing' bioethics in a Reformed context. The proposed model suggested that in order to arrive at responsible ethical decisions, one must refer to both contextual elements and theory. The theoretical grounding for this model was based on the integration of a deontological and virtue ethics approach, arguing that virtue enables persons to know and desire the right moral ends and motivates them to carry out appropriate action toward achieving these ends. An integrative model opens up the possibility whereby bioethics as a systematic tool provides the individual decision-maker with the critical-reflective skills and justification for the ultimate choice that is lacking in the general decision-making processes. This could lead to clearer thinking and increased confidence in the justification of decisions within the Reformed tradition. The proposed hermeneutical perspective on ethical decision-making represents a shift in views about the nature of knowledge and the process of how we come to know. The key to this hermeneutical approach is to acknowledge the dialectic between the universal and the subjectivity of human relations. Working in specific religious communities, one needs to take cognisance of the fact that knowledge is situated in the context of human relationships in which the interpreter participates when articulating the meaning of bioethical experiences. Another aspect that is anticipated lies in the realisation that people struggling with bioethical dilemmas should not be viewed as isolated individuals, but as members of a broader faith community.

'n Geïntegreerde etiese benadering tot bioetiese besluitneming: Voorgestelde model vir predikante. Hierdie artikel het ' $n$ model geskets wat moontlike riglyne aantoon vir die beoefening van bioetiek binne 'n Gereformeerde konteks. Die voorgestelde model argumenteer dat verwysing na beide kontekstuele elemente en teorie onafwendbaar is om tot verantwoordelike bioetiese besluite te kan kom. Die teoretiese begronding vir hierdie model het op die integrasie van deontologiese- en karakteretiek berus en is gebaseer op die argument dat karakteretiek persone in staat stel om die regte morele doelwitte te ken en motiveer hulle ook om die nodige stappe te neem om dit te bereik. 'n Geïntegreerde model skep die moontlikheid vir bioetiek as 'n sistematiese stuk gereedskap om die individuele besluitnemer met die kritiesreflektiewe vaardighede en gronde vir regverdiging van die finale keuses toe te rus, aspekte wat in algemene besluitnemingsprosesse ontbreek. Dit kan ook lei tot helderder denke en groter vertroue in die motivering van besluite binne die Gereformeerde tradisie. Die voorgestelde hermeneutiese perspektief op etiese besluitneming verteenwoordig ' $n$ verskuiwing in aanvaarde sienings oor die aard van kennis en die prosesse wat tot kennis lei. Die sleutel tot hierdie hermeneutiese benadering is om erkenning te gee aan die dialektiek tussen die universele en subjektiewe menslike verhoudings. Dit is veronderstel dat persone wat in spesifieke geloofsgemeenskappe werk daarop ag moet slaan dat kennis binne die konteks van menslike verhoudings - waarbinne die interpreteerder funksioneer - gesetel is wanneer die betekenis van bioetiese ervaring geartikuleer word. ' $n$ Verdere aspek was die erkenning van die feit dat mense wat met bioetiese dilemmas worstel nie as geïsoleerde individue beskou moet word nie, maar as lede van 'n breër geloofsgemeenskap.

\section{Introduction}

Recognising that in the complex world we live in, simplistic answers to complicated questions are not acceptable any more, it has become increasingly important to re-examine the theoretical basis of bioethics as a philosophical grounding or methodology since it is vital for the placing of moral knowledge within such a metatheoretical framework (Grodin 1995:1). It is furthermore important to do so because little is known about decision-making theory in bioethics and ethics consultation in terms of its actual prevalence and practices (Fox, Myers \& Pearlman 2007:13), and doubly so within the tradition of the centred-ethical system which ministers in the Reformed tradition are faced with. 
A professional bioethics will require an ethical method of decision-making which generates both moral discernment and consistent judgments. This can be achieved by providing a methodological framework for bio-ethical decisionmaking that ensures that all relevant data are considered. Acknowledging that correct decisions will not always be made, mistakes can however be avoided. Ethical theory is an essential tool in discussing bioethical questions rationally, whilst keeping in mind that different ethical theories will reveal different parts of the truth about morality. With its emphasis on the authority of Scripture, a Reformed approach should be able to give a coherent account of its method for moving between text and normative ethical judgments. Without it, 'appeals to the authority of Scripture will be hollow and unconvincing' (Hays 1996:3). Bioethics within this tradition should pay attention not only to ethical theory, philosophical foundations and methodology, but also take the interdisciplinary relationship between theology, philosophy and the life sciences seriously in order to move forward as a scientific discipline (cf. De Lange 2009). However, the rationalistic model of linear, step-by-step deduction or induction is too narrow to do justice to the complexities of decision-making in bioethics (Graber \& Thomasma 1989:173). 'Doing' bioethics requires 'significant analytic re-evaluation to help conceptualise, frame, illuminate or resolve real problems in a real world' (Grodin 2001:1), as there is no clear indication of fundamental methodological issues associated with it. ${ }^{1}$ Grundstein-Amado (1991:158) proposed a model of ethical decision-making that consists of three major elements: a critical component (interpreted here as a theoretical framework); a decision-making component, which will be presented as a proposed model; and a contextual component which emphasises the importance of the role of all stakeholders when it comes to ethical decisions.

\section{A theoretical framework}

It is clear that whatever one's meta-ethical preference, to make a good start with bioethical problems means getting involved in this discussion and not shying away from it, '[because] if one does not, basic presuppositions will remain unexamined and the superstructure built upon them will be vulnerable' (McCormick 1987:52). It is therefore unavoidable to formulate a clear ethical theory which can tell us what we mean by the question; what the methods are by which we can hope to formulate an answer; how we can test the worth of our answers; and so forth. Although an ethical theory cannot give us infallible practical guidance, it can show us what the real problem is.

Ethical thinking can be seen as being based on three sets of principles, viz. deontological, teleological and utilitarian principles. ${ }^{2}$ A noticeable recent trend is the renewed interest in principles based on virtues (cf. MacIntyre 1984; Porter 2001; Swanton 2003). A Reformed virtue ethics draws on Aquinas' claim that the virtues, especially theological virtues, 'are

1.For a summary of models that are used in the theory-practice relation, see Graber and Thomasma (1989:3)

2.For a summary of how each of these functions, see Jansen (2006:595-596). the principles through which grace becomes active' (Porter 2001:106). For reflection on the Christian moral life, Stanley Hauerwas claims that the ideas of virtue and character, rather than moral rules, provide the most appropriate framework. ${ }^{3}$ Whilst deontology is regarded by many working in the Reformed tradition as the main framework for Christian ethics, I would argue for a complementary approach between these two theories because I understand virtue as a result of living the law of love (Gl 5:22). Moving from a pure deontological approach to a more integrative approach can lead to clearer thinking and increased confidence about the justification of decisions. Grundstein-Amado (1991:169) views integration as a complementary process, whereby such an integrative approach as a systematic ethical tool provides decision makers with critical choices that are lacking in the general decision-making process.

Before discussing deontology and virtue ethics, it is noteworthy that modern Reformed ethics tends to rely increasingly on 'responsibility' as its organising principle (cf. Dutney 2001:112; Schweiker 1995; Huber 1993; Bonhoeffer 1955). In the Responsible Self, Niebuhr (1963) argues that the moral life is best characterised in terms of responsibility and not obedience to moral laws or commands or pursuit of telos, or goal, which guides our activities (De Villiers 2007:90). Bonhoeffer and Niebuhr, as the two most prominent representatives of a Christian ethics of responsibility in the 20th century, understand the human person as responder, as being responsible firstly to God and secondly to other humans. In the context of the article this responsibility is extended to nature by living out the calling to be stewards on earth. Responsibility is an integral part of all theories used in Christian ethics. The answer to the question, 'Is this action right or wrong?', depends on an examination of all the circumstances surrounding a particular case.

\section{Deontology as creational norm}

For many scholars Christian ethos is primarily a deontological ethics, not an ethics of 'the good' (Ramsey 1950:116; Geisler 2010:17; Vorster 2004:67). Vorster argues that 'casuistry, situation ethics, consequentialism and utilitarianism are valid to some extent in certain extraordinary situations, but fall short of a suitable Christian ethical paradigm' (Vorster 2004:67). Answering Vorster's calling on defining a clear and useful paradigm (2004:67), a critical view on a deontological theory is necessary. Within the framework of a deontological theory, moral decision-making is always subject to the demands of an ethical authority. This article argues that one needs to understand this authority as being rooted in the created character of reality. From a Reformed perspective, this means that our world was created, and is continuously being upheld, by God's creative Word. The entire creation is dependent on God and is subject to God's law: everything which follows is intended to be an extrapolation and implication of this fundamental scriptural stance (Wolters 1985:22).

3. Hauerwas has written extensively. See Hauerwas (1981) and Hauerwas and Pinches (1997), who provide an overall view of his work. 
Another dimension which complements this view is when one considers that in Christian ethics, all moral rules must be in accordance with the example and teaching of Jesus Christ as set forth in the Gospels. These rules must however not be in conflict with the Decalogue and Torah, and can therefore be interpreted as creational norms. From a Christian perspective, in deontology one cannot deny the existence of an omnipresent God and one cannot maintain that only consequences matter (Jansen 2006:596). Being committed to a deontological ethics, Ramsey (1951:107, 115-116, 124, 130) has expressed the character of the Christian moral obligation as obedient response in the covenant. A consideration of consequences remains secondary to the determination of the unconditional demands of agape or covenant fidelity.

Deontological theories deny that right, wrong, obligatory and the like are wholly a 'function of what is normally good over evil for self, one's society, or the world as a whole' (Frankena 1973:15). Madueme (2004) understands deontological ethics as a way of making ethical decisions out of a sense of duty - no matter what the result. This is not to say that Christian ethics disregards results - the results of actions are important in Christian ethics. The difference is that in Christian ethics, these results are calculated within rules and norms. That is, 'no anticipated result as such can be used as a justification for breaking any God-given moral law' (Geisler 2010:18).

Deontological and utilitarian approaches as single principles are significantly incomplete, and now hold a much more diminished stature in the field of ethics in general. Beauchamp and Walters (2003:16-17) identify three disadvantages, one of which is especially noteworthy for bioethical decisionmaking. There is the problem that a highly general principle is indeterminate in many contexts (such as in bioethics) in which one tries to apply it. Single-principle theories frequently depend on independent moral considerations, with the help of which the theories can serve as effective guides to action. I shall argue for a Christian ethics that does not only consist of rules, but one in which virtue, attitude and motive are all involved in ethical judgement. This is in agreement with the scriptural call for love towards God and one's neighbour. There is thus both a horizontal and vertical relationship involved in the practical manifestation of Christian ethics (Jochemsen \& Cusveller 1992:17-18). For Overduin (2006:583), it is obvious that Christian ethics or theological ethics in the Christian tradition surpasses the boundaries of a strict deontological ethical theory (cf. Mt 5:38-42). What Mahoney calls an 'ultimate moral resource' (Mahoney 2003:721) is to be found in beliefs about God, and that God's own values are revealed in our understanding of what God has done for humanity. Opting for a Christian ethics, which is neither obsessed by rules nor subordinated to consequences, offers a much more productive route for bioethics. We now turn to recreational norms, viz. theological virtues, as a supplement to deontological theory in devising a framework for Christian bioethics.

\section{Theological virtues as recreational norms}

People facing difficult bioethical dilemmas face them 'not as blank slates but as people with certain virtues and vices, with various character traits that orient them toward good or evil' (Van Drunen 2009:15). These personal virtues cannot only motivate their possessors to bring about changes that move beyond duty in themselves, but also in the world at large (Zagzebski 1996:246). In proposing a clarification of the term, MacIntyre (1984) defined virtue in a preliminary way as:

$[A] n$ acquired human quality, the possession and exercise of which tends to enable us to achieve those goods which are internal to practices and the lack of which effectively prevents us from achieving any such goods. (p. 191)

In order to understand the context of theological virtues, it is important to briefly state the history of this concept. Virtue ethics descended from the classical Greek tradition represented by Plato and Aristotle. In this sense, Porter (2001) indicates two sources that have been formative for Christian reflection on virtues, namely:

[T] he ideals and theories of virtue which emerged in Greek antiquity and were further elaborated in the Hellenistic Roman empire, and the ideals of virtue set forth or implied in scripture. ${ }^{4}$ (p. 97)

Paul offers a number of lists of such Christian virtues, for example in Galatians 5:22ff and 1 Corinthians 13:13. These virtues, as well as those inherent in the Sermon on the Mount, are the virtues by which Christians are expected to live and shape their lives up to the present day. The whole Christian life must therefore be a process of striving after the virtues to which Scripture calls us (Van Drunen 2009:70). Virtues should allow us to meet new contemporary situations like those faced in bioethics, and equip us to skilfully make decisions that reflect good judgements and decision-making skills.

Norheim (2004:108-110) has found that not only do recent studies in virtue ethics devote little attention to the theological virtues, but also that there is confusion concerning their form and content. He distinguishes between theological virtues (faith, hope and love), and cardinal virtues (prudence, justice, temperance and fortitude), and considers the cardinal virtues as being subordinate to the particular theological virtues. Interestingly enough, he also describes the modern Roman Catholic eschatological virtues (gratitude, humility, vigilance, serenity and joy), as gifts of the Holy Spirit bestowed on the believer. This echoes Aquinas' view on theological virtues as being instilled and revealed by God despite working from human nature. Intellectual and moral virtues may therefore only function as a presupposition for integrating theological virtues (Norheim 2004:121-113).

In Schleiermacher's view, ethical reasoning necessitates three ideas, namely the highest good, duty, and virtue. He interprets virtue as a capacity acting upon the concrete

4.See Maclntyre (1984:121-164) and Barton (1999:12-22) for a helpful discussion of both these sources. 
implications of moral law (Herms 1982:481-495). The 'motive' theme is further developed by Zagzebski when she distinguishes between two forms of pure virtue theory: happiness-based and motivation-based theories. She demonstrates that motivation-based theory can be developed in ways that adequately handle epistemic evaluation. She calls on experience in determining what makes a motivation a good one (Zagzebski 1996:77, 83). As already indicated, religious experience arises from, and transcends the social, ethical, moral and aesthetic dimensions of our reality and can therefore provide the motivation for using theological virtues for a specific good, namely holiness and merit. In the Reformed context, a recreational view on virtues is based on the Christian hope grounded in the reign of God, a view that implies theological virtues as spelt out in Scripture. In this sense, virtues as recreational norms have practical value in that a morally good person with the right desires or motives is more likely to understand what should be done and perform the required acts.

One positive characteristic of virtue theory is that it may provide us with a parallel explanatory account of how it is that our ethics and our epistemology are so closely related (Thacker 2007:103). In this sense, and of cardinal importance to this article, is the conclusion that it is possible to relate virtuebased ethics to deontological theories in a comprehensive moral philosophy of bioethical decision-making. DeaneDrummond (2003:225) suggests that the language of virtue invites reflection in such a way that a space is opened up for dialogue between those of different presuppositions, including scientists (cf. De Lange 2009). In arguing that it is not a rigid scheme based on particular 'foundations', but rather, by being eschatological in orientation, it explores through a particular theological telos, what might be the better end for humanity. Deane-Drummond (2003:235) argues that the contribution that virtue ethics can make is to mediate between the extreme of a Kantian deontology and postmodern deconstruction, and so lend itself to a resonance of shared concern across the wider human community. This would mean that those of no religious persuasion would be included.

It is not difficult to see the compatibility of virtue ethics with deontology when arguing that an ethical theory is more complete if the virtues are included and that moral motives deserve to be at centre stage in a way some leading traditional theories have inadequately appreciated' (Beauchamp \& Walters 2003:1). In this sense Aquinas' claims, that the theological virtues are the principles through which grace becomes active, are particularly important for formulating a framework for reflection when bioethical decisions are contemplated.

\section{Decision-making theory: A proposed model}

Making bioethical decisions is a complex matter because these judgements are informed by a variety of factors. By opting for a practical model of bioethical hermeneutics that combines both theory and practice, we can attempt to resolve the deeper metaphysical questions of the relation between the two. This will, however, call for a realisation that a hermeneutical methodology contains different components, viz. context, data, subject-matter, method and acknowledgement of presuppositions or principles of interpretation. ${ }^{5}$ Every method or strategy consists of two phases - one that directs attention to the gathering of facts, and another that applies evaluated standards. The process of making moral decisions within a particular community or tradition can be as important as the decision itself because 'one's praxis is decisively shaped by the theological or metaphysical system underpinning it ...' (O'Neil 2006:21). The basic assumption of this article is that bioethical decisions will be better made if they are not done in a habitual way, but are rather based on a systematic analysis or method.

Several strategies for making ethical decisions are reported in the literature (cf. Martin 1978; Candee \& Puka 1983; Pellegrino 1997; Cottone \& Claus 2000:275-283; Häyry \& Takala 2003:95-97; Jochemsen 2003; Whitney 2003; McMinn \& Runner 2004:56). An important feature that is imperative for the attainment of a desirable moral end is to integrate ethics and decision-making into a synergistic complementary process. Grundstein-Amado (1991:158) proposes two underlying assumptions:

- Decision-making is a process of choice leading to action, and both are influenced by context (relationships, etc.) and content (specific data);

- Action is an expression of the decision-makers personal, cultural and religious values, and of his/her ideological position, which is justified through a process of appealing to ethical principles and theories.

Given the argument presented thus far and drawing on the work done by Rae and Cox (1999:298-300), GrundsteinAmado (1991) and Borry, Schotsmans and Dierickx (2004), I wish to propose a decision-making model that will show how it is possible to arrive at an ethically-justifiable, sound decision in bioethics by enlarging the ministers' conceptual space beyond their past experience within a specific tradition, and consequently, by developing a meaningful understanding of new concepts with which they are confronted. It is important to take into consideration that the model must not be used as a 'formula', but rather as a guide with which to navigate the confusing maze of facts and feelings so often associated with bioethical dilemmas. The proposed model must therefore be viewed as exploratory and not final. In opting for a shared decision-making scenario, ${ }^{6}$ the role of both the minister and the congregation member engaged with all the aspects as indicated, is that of the congregation member being the primary decision-maker, with the minister as guide and counsellor since most bioethical decision have a substantial impact on people's lives, or on the environment.

5.The importance of hermeneutics for the bioethical endeavour has already been dealt with in another article. See De Lange (2012).

6.Shared decision-making is widely accepted as an ethical imperative (Brody 1992; Emanuel \& Emanuel 1992). 
The proposed methodological model consists of eight facets.

\section{Identify the bioethical problem or problem perception}

The first is to distinguish between the ethical and technical components when trying to come to a clear understanding of the very nature of the bioethical dilemma. GrundsteinAmado (1991:161) explains this important step by referring to the fact that decisions contain both factual and ethical content. The factual can be viewed as a descriptive mode of action that can be proven true or false, whilst the ethical on the other hand has an imperative qualitative dimension.

\section{Information processing or Identify potential issues involved}

Frequently ethical dilemmas can be resolved by simply clarifying the facts of the case in question. Questions to be asked are 'what do we know?', and 'what do we need to know?' in order to make an intelligent informative bioethical decision. Here one tries to determine the technical or scientific facts of the case by investigating all factors that not only define the problem, but also to seek other sources as indicated earlier in the article. This could include identifying relevant values and goals, principles and moral guidelines, scriptural guidelines, canons and loyalties, relational objective norms, integrity and virtues, et cetera, that could inform the decision.

When identifying the ethical issues in terms of competing interests or goods it is critical to jointly identify the moral value considerations, or norms, which are central to the competing positions being taken. Not only principles should be taken into consideration, but also theological virtues and broader theological paradigms. The narrative of one's life and the community may have a bearing on the specifics of the case as well.

\section{Seeking specialised help}

When necessary, seek the expertise of scholarly experts in ethics, professionals in the field of enquiry, legal advice, and consult with them and colleagues in the ministry.

\section{Listing alternatives}

Creative thinking required for resolving ethical dilemmas and striving for consistency involves generating various alternative courses of action - one may come up with creative alternatives not previously considered which in turn could lead to the selection of a particular course of action. At this point, the task is to eliminate alternatives according to the moral norms that have a bearing on the case. In many instances the case will be resolved at this point, since the norms will eliminate all alternatives except one. In focusing on the process of choosing amongst alternatives, the selection of a particular course of action can be made.

\section{Listing consequences}

Enumerate the consequences of different decisions by considering both positive and negative consequences.

\section{Hermeneutics and exegesis of all the information}

Viewing the nature of the knowledge and sources is an important part of the process of how we come to know in bioethical decision-making. For Betan (1997) hermeneutics presents a shift in how we view that nature in knowledge, since 'knowledge is situated in the context of human relationships in which the interpreter (as knowledge interpreter) participates in narrating meaning' (Betan 1997:352). The key to a hermeneutical approach is to acknowledge that our sense of what is, for example, a standard or a principle, is a product of shared subjective experiences, which in turn are embedded in the context of the tradition from which we interpret.

\section{Make the choice}

Decide on the best course or potential courses of action as deliberations cannot go on forever.

\section{Justification/Evaluation/Reflection}

Defend the course of action based on the values informing it. Evaluate the selected course of action and reflect on the whole process. How did I make this decision? What norms and values were involved? To what extent is my decision determined by tradition, economic, cultural or sociohistorical factors and so on?

\section{Contextual components}

Contextual features include the impact of the decision not only on family members, but also on the community, cultural and religious relations and the environment where applicable. From this vantage point, the ethical analysis will focus on the total context of moral ambiguity in that all the stakeholders must be acknowledged, ${ }^{7}$ all of which will influence the final course of action. 'Doing' bioethics within a specific religious community is decisively shaped by the theological and therefore metaphysical system on which it is based.

\section{The relational context}

The relational context involves the minister's relationship with his congregants, and implies a relationship of participatory, shared decision-making. Grundstein-Amado (1991:164) talks about a mode of advocacy - the congregation member exercises the decisional authority. The minister provides information, advice and spiritual guidance, and consequently enables the person to make an ethical decision in a constructive manner. It should be noted however, that the participatory and advocacy modes incorporate certain hermeneutical aspects, such as those which propose a dialectical relationship between the exploratory powers of science and the need for these explanations to be modified by and understood through the congregant's own terms and context.

\section{The organisational context}

This includes the division of work, standards, procedures and policy guidelines, the line of authority, and the communication 7.For a critique of contextual components see McMillan (1986:132). 
system. The way information is communicated is crucial because the more information there is, and the better the system of communication itself, the easier it will be to clarify problems, solutions and consequences. Ministers cannot distance themselves from all these contextual issues which imply that congregants should be dealt with not as isolated individuals but as members of a religious community who take responsibility for one another.

\section{Conclusion and recommendations}

This article has set out to deal with the theory of ethics by focusing on those aspects of Reformed epistemology and proposing a methodology to enable ministers to play their pastoral role in guiding congregation members concerning bioethical decision-making. This was achieved by critically reviewing Reformed epistemology and methodology within the context of Christian theological ethics in particular. Placing bioethics within the Reformed Christian world view, reasoning is informed in a way that acknowledges that concrete answers are not found in the tradition alone, but also in the intelligent use of our unique ability for rational judgment. This article has drawn on the argument put forward by Mourad in which he finds in theoretical knowledge the foundation for practical knowledge, and in theoretical activity, the foundation for practical activity (Mourad 1997:127-128). Thus, in 'doing' ethics by bringing all one's knowledge into a practical reality where answers of a practical nature are concerned, theory can be seen as bridging this void. This critical judgement, when applied to making decisions in difficult bioethical situations, calls on our moral epistemology that is concerned with 'whether and how we can have knowledge or justified belief about moral issues' (Moser 2002:23). An important question to answer in bioethical decision-making lies in the main concern of epistemology, not only to decide on what actions are morally right or wrong, but also to indicate the possible sources for theological knowledge as well as to provide an indication of the task of exegesis and interpretation. The importance of discussing moral questions within a methodological framework has been highlighted, arguing that this is best done within the context of both creational and recreational norms as a theological framework.

Grounding bioethical arguments in a specific theological tradition provides more specific, clear and reliable norms that can be applied consistently and comprehensively to complex situations. This, however, presumes that the minister speaks with an authority grounded in specialist knowledge, referring back to the acknowledged sources. Theocentric ethics requires that we understand that we are interactive participants in the divine ordering of the whole of creation. Van Huyssteen (1998) describes the primary task of the critical theologian and therefore the minister in the congregation, as being able:

$[T]$ o examine tradition, not just repeat it, and through critically examining the tradition to allow the present to be reshaped more closely along the lines of what the tradition truly stands for. (p. 217)
The minister working within a specific tradition may be confronted with questions that cannot be resolved by its own resources alone. An interdisciplinary awareness may lead us to formulate better and more grounded answers and guidance in this regard because, as mentioned, dealing with bioethical challenges directly from Scripture alone, reveals a serious vulnerability in Christian ethical method. It is therefore unavoidable for a Christian ethics, if it hopes to remain at all relevant to contemporary society dealing with issues that Scripture does not directly address, and for the Reformed tradition in particular, to develop a methodology that will not only help improve our argumentation on bioethical issues, but also our general ethical method and our everyday moral decision-making. 'No Christian bioethics could exist disconnected from Christian ontology.' (Erickson 2005:273-274). We must therefore explore not only the theological doctrines and theoretical frameworks that define our faith and life generally, but also have special importance for the challenges that arise from contemporary bioethics.

Within such a framework, a possible model for guidance in 'doing' bioethics in a Reformed context was outlined. My aim was to propose a new, comprehensive model that will address deficiencies in some of the previous practice-models advocated for ethical decision-making in relying on a shared responsibility. The proposed model suggests that in order to make responsible ethical decisions, one must make reference to theory, decision-making and contextual elements. An integrative model was proposed whereby bioethics as a systematic tool provides the individual decision-maker with the critical-reflective skills and the justification of the ultimate choice that is lacking in the general decisionmaking processes, recognising that in the complex world we live in, simplistic answers to complicated questions are not acceptable anymore. Employment of an integrative model can therefore lead to clear thinking and increased confidence in the justification of decisions within the Reformed tradition.

There is however, much work still to be done on refining this decision-making model in order to determine how it could be applied in practice and do full justice to the complex interactions in contemporary bioethics. One positive aspect that is anticipated lies in the realisation that people struggling with bioethical dilemmas must be dealt with not as isolated individuals, but as members of a broader faith community.

The Reformed tradition began as a movement of protest, and is one of affirmation and testimony. A theological bioethics that neglects this role, also neglects the 'internal' ministry of the church, which can prepare its people to address dilemmas that arise in contemporary bioethics. In order to deal with complex technological challenges not only in medicine, but also in ecological and other systems, Christians must be helped to think not only theologically, but 'Christianly' as well. We need to develop a bioethics that is sufficiently informed and enriched in order to be relevant. My thesis is that Reformed ethics is something that needs to be constantly reconstructed in the spirit of Semper Reformanda - then, and only then, will it be able to provide these relevant answers to complex bioethical questions. Only then will a Reformed-inspired bioethics be able to function and interact with the broader culture. 
The minister is at the service of the church-in-the-world, and can no longer shy away from viewing decision-making as an interactive process between him and the members of his congregation. The minister as bioethicist helps in providing a more accurate understanding of the issues and possibilities for decisions and action. He should try to strengthen the reflective-cognitive element in the decision-making process, placing emphasis on epistemological skills in order to contribute meaning and significance to bioethical data, and also on the importance of understanding one's own values in order to reach a responsible and appropriate decision in a given situation. Echoing Hanford's (2002:7) call that 'we need (ministers in the RSCA) to interpret bioethics from their faith-perspective', and the need to build it on sound academic grounds, this article has tried to contribute to and underlie the development of an effective professional ministry in bioethics.

\section{Acknowledgements Competing interests}

The author declares that she has no financial or personal relationship(s) which may have inappropriately influenced her in writing this article.

\section{References}

Barton, J., 1999, 'Virtue in the Bible' Studies in Christian Ethics 12(1), 12-22. http:// dx.doi.org/10.1177/095394689901200103

Beauchamp, T.L. \& Walters, L.R., 2003, Contemporary issues in Bioethics, 2nd edn. Wadsworth, Belmont.

Betan, E.J., 1997, 'Toward a hermeneutic model of ethical decision making in clinical practice' Ethics and Behaviour 7, 347-365. http://dx.doi.org/10.1207/ s15327019eb0704_6

Bonhoeffer, D., 1955, Ethics, Bethge, E., (ed.), SCM Press, London.

Borry, P., Schotsmans, P. \& Dierickx, K., 2004, 'What is the role of Empirical research in bioethical reflection and decision-making? An ethical analysis' Medicine, Health Care and Philosophy 7(1), 41-53. http://dx.doi.org/10.1023/ B:MHEP.0000021844.57115.9d

Brody, H., 1992, Healer's power, Yale University Press, New Haven, CT.

Candee, D. \& Puka, B., 1983, 'An analytical approach to resolving problems in medical ethics', Journal of Medical Ethics (9/10), 61-69.

Cottone, R.R. \& Claus, R.E., 2000, 'Ethical decision-making models: A review of the literature', Journal of Counselling \& Development (78), 275-283. http://dx.doi. org/10.1002/j.1556-6676.2000.tb01908.x

Deane-Drummond, C., (ed.), 2003, Brave new world? Theology, ethics and the human genome, Continuum/T\&T Clark, London.

De Lange, M.C., 2009, 'Exploring Interdisciplinarity: A theoretical consideration of Bioethics at the interface between Theology, Philosophy and Life Sciences', The Journal of Transdisciplinary Research in Southern Africa 5(2), 1290-1216.

De Lange, M.C., 2012, 'Dealing with bioethical dilemmas: A survey and analysis of responses from ministers in the Reformed Churches in South Africa', HTS
Teologiese Studies/Theological Studies 68(1), Art. \#882, 10 pages. http://dx.doi. Teologiese Studies/Theological
org/10.4102/hts.v68i1.882.

De Villiers, D.E., 2007, 'Prospects of a Christian ethics of responsibility (Part 2): An assessment of three German versions', Verbum et Ecclesia 28(1), 88-109.

Dutney, A., 2001, Playing God: Ethics and faith, Harper Collins Religions, Melbourne.

Emanuel, E.J. \& Emanuel, L.L., 1992, 'Four models of the phycisian-patien relationship', Journal of the American Medical Association 267(16), 2221-2226. http://dx.doi.org/10.1001/jama.1992.03480160079038

Erickson, S.A., 2005, 'On the Christian in Christian Bioethics', Christian Bioethics 11 269-279. http://dx.doi.org/10.1080/13803600500402317 PMid:16423731

Fox, E., Myers, S. \& Pearlman, R.A., 2007, 'Ethics consultation in United States hospitals: A national survey', The American Journal of Bioethics 7(2), 13-25. http://dx.doi.org/10.1080/15265160601109085 PMid:17366184

Frankena, W.F., 1973, Ethics, 2nd edn., Prentice-Hall, Englewood Cliffs, NJ.

Geisler, N.L., 2010, Christian Ethics: Contemporary issues and options, 2nd edn., Baker Academic, Grand Rapids, MI.

Graber, G.C. \& Thomasma, D.C., 1989, Theory and Practice in Medical ethics, Continuum, New York.

Grodin, M.A., (ed.), 1995, Meta Medical Ethics: The philosophical foundations of Bioethics, Kluwer, Dordrecht. (Boston Studies in the Philosophy of Science, vol 171)

Grodin, M.A., 2001, Meta Medical Ethics: The philosophical foundations of Bioethics, Kluwer, Dordrecht.
Grundstein-Amado, R., 1991, 'An integrative model of clinical-ethical decision making' Theoretical Medicine 12, 157-170. http://dx.doi.org/10.1007/BF00489796 PMid:1896954

Hanford, J., 2002, Bioethics from a faith perspective: Ethics in health care for the twenty-first century, The Haworth Pastoral Press, New York, NY.

Hauerwas, S., 1981, A community of character, University of Notre Dame Press, Notre Dame, IN.

Hauerwas, S. \& Pinches, C., 1997, Christians among the virtues: Theological conversations with ancient and modern ethics, Notre Dame Press, Notre Dame, IN.

Häyry, M. \& Takala, T., (eds.), 2003, Scratching the surface of bioethics, Rodopi, Amsterdam.

Hays, R.B., 1996, The Moral Vision of the New Testament: Community, Cross, New Creation, Continuum /T\&T Clark, London.

Herms, E., 1982, 'Virtue: A neglected concept in Protestant ethics', Scottish Journal of Theology 35, 481-495. http://dx.doi.org/10.1017/\$0036930600055484

Huber, W., 1993, 'Toward an ethics of responsibility', The Journal of Religion 73(4), 573-591. http://dx.doi.org/10.1086/489259

Jansen, R.P.S., 2006, 'A practical ethical framework for In Vitro fertilization and related reproductive interventions', Annuals of the New York Academy of Science 442, 595-600. http://dx.doi.org/10.1111/j.1749-6632.1985.tb37573.x PMid:3860064

Jochemsen, H., 2003, Ethiek van de zorg tussen technische beheersing en professionele hulpverlening, Christelijke Hoogenschool Ede, Ede.

Jochemsen, H. \& Cusveller, B.S., (eds.), 1992, Christelijke oriëntasie in medischetiesche onderwerpen, Buijten \& Schipperheijn, Amsterdam.

MacIntyre, A.S., 1984, After Virtue: A study in moral theory, 2nd edn., Duckworth, London.

Madueme, H., 2004, 'Thinking theologically about Bioethics', The centre for Bioethics and Human Dignity, viewed 18 February 2009, from, http://www.cbhd.org/ resources/bioethics/madueme_2004-11-12.htm

Mahoney, S.J., 2003, 'Christian doctrines, ethical issues, and human genetics', Theological Studies 64(4), 719-749.

Martin, A., 1978, 'A clinical model for decision-making, Journal of Medical Ethics 4 200-206. http://dx.doi.org/10.1136/jme.4.4.200 PMid:739517 PMCid:1154684

McCormick, R.A., 1987, 'Bioethics and Method: Where do we start?', in S.E. Lammers \& A. Verhey (eds.), On moral medicine: Theological perspectives in medical ethics, pp. 45-54, Eerdmans, Grand Rapids, MI.

McMillan, R.C., 1986, 'Bioethical decision making: Where the buck stops', Perspectives in Religious Studies 13(2), Summer, 125-136.

McMinn, M.R. \& Runner, S.J., 2004, 'Why should Christian counsellors care about ethics research?', Christian Counselling Today 12(4), 56-59.

Moser, P.K. (ed.), 2002, The Oxford Handbook of Epistemology, Oxford University Press, Oxford.

Mourad, N., 1997, 'Postmodern Interdisciplinarity', The Review of Higher Education 20(2), 113-140. http://dx.doi.org/10.1353/rhe.1996.0012

Niebuhr, H.R., 1963, The responsible self: An essay in moral Philosophy, Harper and Row, New York, NY.

Norheim, B. Jr., 2004, 'The Theological Virtues, Aquinas did, but did Kant?' Studia Theologica 58, 108-122. http://dx.doi.org/10.1080/00393380410012745

O'Neil, M., 2006, 'Ethics and epistemology: Ecclesial existence in a postmodern era' Journal of Religious Ethics 34(1), 21-40. http://dx.doi.org/10.1111/j.14679795.2006.00254.x

Outka, G., 2005, 'Christian Ethics', in W. Schweiker, The Blackwell companion to religious ethics, pp. 197-203, Blackwell, Oxford.

Overduin, D., 2006, 'Bioethical decision-making, Which path to choose?', Annals of the New York Academy of Sciences 442, 583-584. http://dx.doi. Annals of the New York Academy of Sciences 442,
org/10.1111/j.1749-6632.1985.tb37570.x PMid:3860061

Pellegrino, E.D., 1997, 'The anatomy of clinical ethical judgments in perinatology and neonatology: A substantive and procedural framework', Semin Perinatol 11 202-209.

Porter, J., 2001, 'Virtue ethics', in R. Gill (ed.), The Cambridge companion the Christian ethics, pp. 96-111, Cambridge University Press, Cambridge.

Rae, S.B. \& Cox, P.M., 1999, Bioethics: A Christian approach in a pluralistic age, Eerdmans, Grand Rapids, MI.

Ramsey, P., 1950, The Patient as Person, Yale University Press, New Haven, CT.

Ramsey, P., 1951, Basic Christianity, Scribner's, New York, NY.

Schweiker, W., 1995, Responsibility \& Christian Ethics, Cambridge University Press, Cambridge.

Swanton, C., 2003, Virtue ethics: a pluralistic view, Oxford University Press, Oxford.

Thacker, J., 2007, Postmodernism and the ethics of Theological Knowledge, Ashgate, Aldershot.

Van Drunen, D., 2009, Bioethics and the Christian Life: A Guide to making difficult decisions, Crossway Books, Wheaton, IL.

Van Huyssteen, W., 1998, 'Tradition and the task of Theology', Theology Today July, 213-228. http://dx.doi.org/10.1177/004057369805500206

Vorster, J.M., 2004, Ethical perspectives on human rights, Potchefstroom Theological Publications, Potchefstroom.

Whitney, S.N., 2003, 'A new model of medical decisions: Exploring the limits of shared decision making', Medical Decision Making 23, 275-280. http://dx doi. org/10.1177/0272989X03256006 PMid:12926577

Wolters, A., 1985, Creation regained: Biblical basics for a Reformational worldview, Eerdmans, Grand Rapids, MI.

Zagzebski, L.T., 1996, Virtues of the mind: An inquiry into the nature of virtue and the ethical foundations of knowledge, Cambridge University Press, Cambridge. http:// dx.doi.org/10.1017/CBO9781139174763 